\title{
Serum levels of FGF21 are reduced and negatively correlated with adiponectin in children with Prader-Willi syndrome
}

\author{
Su Jin Kim ${ }^{1 *}$, Young Bae Sohn ${ }^{2}$, Sung-Yoon Cho ${ }^{3}$, Young Ok Choi ${ }^{4}$, Chi Hwa Kim ${ }^{4}$, Dong-Kyu Jin ${ }^{3}$ \\ From 7th APPES Biennial Scientific Meeting \\ Nusa Dua, Bali. 14-17 November 2012
}

\section{Background/Aims}

FGF21 (fibroblast growth factor 21) is a novel metabolic regulator that has beneficial effects on glucose homeostasis and insulin sensitivity. In human obesity, serum FGF21 level was increased. The aims of this study were comparing fasting serum levels of FGF21 in Prader-Willi syndrome (PWS) and obese control children and finding correlations these levels with insulin sensitivity and obesity-related parameters.

\section{Methods}

Sixteen children (median age, 10 years; interquartile range, 9.0-13.5 years) with PWS were matched with 16 control subjects (median age, 10.5 years; interquartile range, 9.512.5 years). We measured serum levels of FGF21, adiponectin, insulin sensitivity and obesity-related parameters during oral glucose tolerance test.

\section{Results}

Waist to hip ratio and HOMA-IR were lower in PWS individuals relative to control subjects. Remarkably, serum levels of FGF21 were lower and adiponectin were higher in PWS subjects than in control subjects. FGF21 levels were significantly positively correlated with HOMA-IR and negatively correlated with adiponectin.

\section{Conclusion}

Previously, FGF21 level was reported to increase with obesity. However, compared with obese controls, our results show PWS individuals have lower FGF21 levels. Our data suggest that insulin sensitivity, lower waist to hip

'Departmnet of Pediatrics, Kwandong University College of Medicine Myongji Hospital, Goyang, Korea

Full list of author information is available at the end of the article ratio, lower FGF21 levels and higher adiponectin levels are the characteristics of PWS children.

\section{Authors' details}

'Departmnet of Pediatrics, Kwandong University College of Medicine Myongji Hospital, Goyang, Korea. ${ }^{2}$ Department of Medical Genetics, Ajou University Hospital, Suwon, Korea. ${ }^{3}$ Department of Pediatrics, Samsung Medical Center, SungKyunKwan University School of Medicine, Seoul, Korea. ${ }^{4}$ Clinical Research Center, Samsung Biomedical Research Institute, Seoul, Korea.

Published: 3 October 2013

\section{doi:10.1186/1687-9856-2013-S1-P52}

Cite this article as: Kim et al: Serum levels of FGF21 are reduced and negatively correlated with adiponectin in children with Prader-Willi syndrome. International Journal of Pediatric Endocrinology 2013 2013(Suppl 1):P52.
Submit your next manuscript to BioMed Central and take full advantage of:

- Convenient online submission

- Thorough peer review

- No space constraints or color figure charges

- Immediate publication on acceptance

- Inclusion in PubMed, CAS, Scopus and Google Scholar

- Research which is freely available for redistribution
C Biomed Central

\section{() BioMed Central}

